\title{
Association between Chrysaora plocamia (Cnidaria, Scyphozoa) and Hyperia curticephala (Peracarida: Amphipoda) in Mejillones Bay, Northern Chile
}

\author{
Asociación entre Chrysaora plocamia (Cnidaria, Scyphozoa) e Hyperia curticephala \\ (Peracarida: Amphipoda) en Bahía de Mejillones, norte de Chile \\ Marcelo E. Oliva ${ }^{1}$, Alexis Maffet ${ }^{1}$ and Jürgen Laudien ${ }^{2}$ \\ ${ }^{1}$ Instituto de Investigaciones Oceanológicas, Facultad de Recursos del Mar, \\ Universidad de Antofagasta, P.O. Box 170, Antofagasta, Chile \\ ${ }^{2}$ Alfred Wegener Institute for Polar and Marine Research, \\ Am Alten Hafen 26, D-27568, Bremerhaven, Germany \\ meoliva@uantof.cl
}

\begin{abstract}
Resumen.- Se registra Hyperia curticephala (Amphipoda) viviendo en asociación con Chrysaora plocamia (Scyphozoa). Cinco ejemplares de C. plocamia presentaron entre 39 y 328 especímenes de $H$. curticephala. No hay evidencia estadística de correlación entre diámetro de umbrela y número de anfípodos, gráficamente es evidente una tendencia positiva. $H$. curticephala debe considerarse microdepredador y no
\end{abstract}

\section{Introduction}

Zooplanktivores are an important link between primary consumers and higher trophic levels (Thiel et al. 2007). Off Chile by far the best studied zooplankton taxa are copepods, euphausids (e.g. Hidalgo \& Escribano 2001, Escribano et al. 2007) and gelatinous plankton (Palma 1994). Although considered to be among the most abundant groups of crustacean zooplankton in the pelagic realm (Gasca 2003) the information on hyperiid amphipods is scarce. In the North Pacific these pelagic crustaceans are the fifth most abundant zooplankton taxon (Shulenberger 1978); they have, however, attracted little attention, particularly in the Southern Hemisphere. Hyperiid amphipods are commonly not adapted to a pelagic free-living existence and most of them use gelatinous zooplankton as a substrate (e.g. Laval 1980, Gasca \& Haddock 2004) and thereby affect their host. Thus, they are classified as strict parasites (Dittrich 1992). This relation has also been considered as ectocommensalism, endocommensalism, protection and micropredation (Vader 1983).

Higher temperatures have a strong positive effect on abundances and diversity of Cnidarians in coastal waters (Palma \& Rosales 1995). Off northern Chile gelatinous zooplankton, such as the scyphozoan medusa Chrysaora parasitoide como ha sido sugerido para asociaciones entre hypéridos y plancton gelatinoso. Este registro extiende la distribución del anfípodo en aproximadamente $18^{\circ}$ de latitud hacia el sur y corresponde al primer registro de un anfípodo asociado con medusas en Chile.

Palabras clave: Anfípodos hipéridos, sistema de afloramiento de la Corriente de Humboldt, microdepredador

plocamia (Lesson, 1830), reaches comparatively high abundances in shallow waters during the warm season (December-February) (pers. observ.). The record of the associated hyperiid amphipod Hyperia curticephala Vinogradov \& Semenova, 1985 is the first from the Chilean Pacific. This discovery extends the geographical range of $H$. curticephala approximately $18^{\circ}$ southward, and quantitative characteristics of the association are described.

\section{Material and methods}

In February 2005, high numbers of C. plocamia were observed in the surface water of Mejillones Bay $\left(23^{\circ} \mathrm{S}\right)$ (Fig. 1). These medusae were hosting hyperiid crustaceans inside their umbrella tissue. To ensure an accurate sampling of the symbionts five medusae were caught individually with plastic containers (20 L) directly from the board of a boat and transported separately to the laboratory. Each host species and its associated hyperiid amphipods were examined in vivo and the amphipods fixed in 4\% formaldehyde for taxonomic identification. Gut content of selected hyperiids specimens was studied. In order to detect the significance of the relationship between umbrella diameter (measured with a ruler $\pm 1 \mathrm{~cm}$ precision) and number of hyperiids, the Pearson correlation coefficient was calculated. 


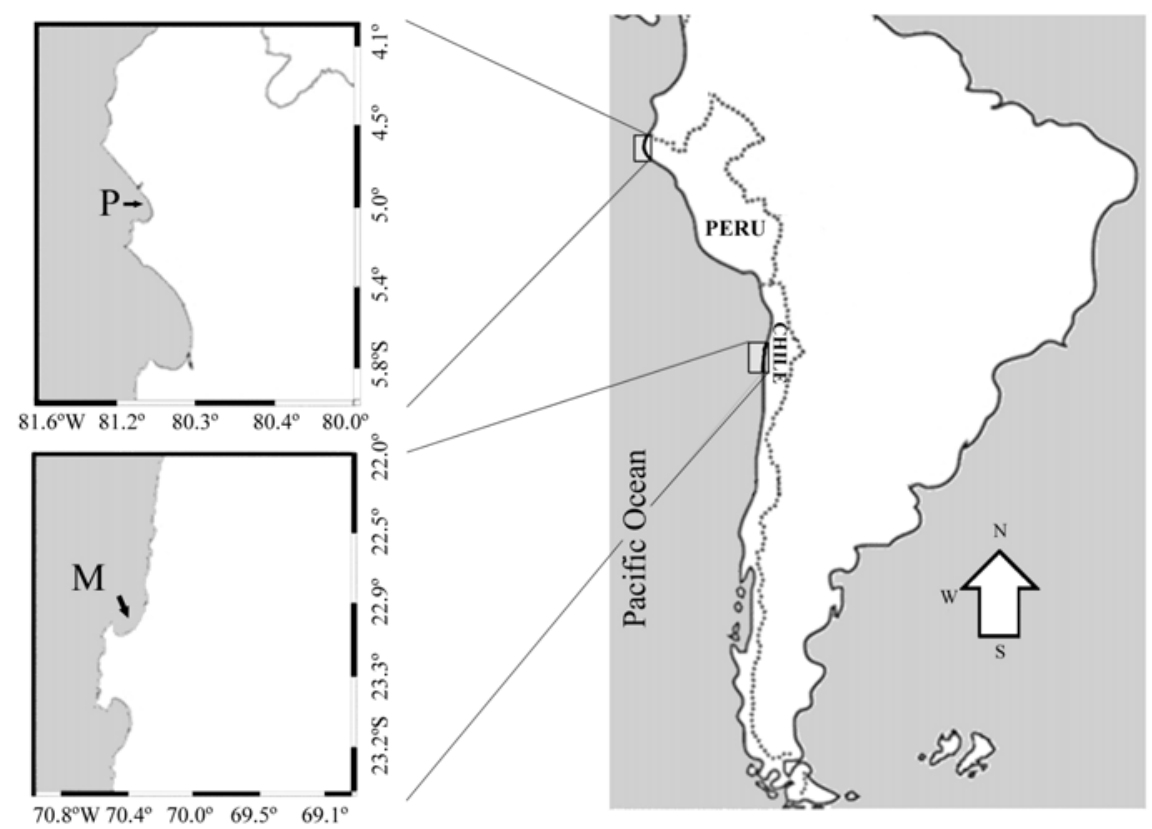

Figure 1

Location of Paita Bay (P), northern Peru and Mejillones Bay (M), northern Chile

Localización de Bahía de Paita (P) norte del Perú y Bahía de Mejillones (M), norte de Chile

Representative specimens were deposited in the Zoological Museum - Universidad de Concepción, Chile, under accession numbers MZUC/UCCC33199 and MZUC/UCCC33200.

\section{Results}

Morphological characteristics of the amphipod agreed well with the description of Hyperia curticephala. Bell diameters of $C$. plocamia ranged from 10 to $26 \mathrm{~cm}$. All hyperiids were identified as Hyperia curticephala (Vinogradov \& Semenova 1985), an amphipod described from the same host in coastal waters of Paita Bay (504'S), northern Peru (Fig. 1).

A total of $871 \mathrm{H}$. curticephala were obtained from the five individuals of $C$. plocamia. The mean number of amphipods per jellyfish was $174.2 \pm 117.3$ (SD) showing an aggregated distribution (variance/mean ratio $=79.95$ ). In total $21 \%$ of $H$. curticephala were male and $79 \%$ were female. A subsample of 114 females were analyzed for eggs and $11.4 \%$ of the dissected females harboured eggs in the brood pouch, number of egg ranged from 1 to 27 (average $=7.15, \mathrm{SD}=8.13$ ). The regression analysis marginally did not support a significant relationship between bell diameter and number of hyperiids $\left(r^{2}=0.72\right.$, $\mathrm{df}=3, P=0.069$ ) but a trend is apparent from graphical observation (Fig. 2).

Additionally, gut contents of ten $H$. curticephala were analyzed revealing that small portions of host mesoglea, but no nematocyst were found ingested in the specimens dissected.

\section{Discussion}

Although the data set is limited, some conclusions can be drawn. Laval (1980) stated that hyperiids inhabiting small hosts self limit the number of larvae deposited as a mechanism to avoid intraspecific competition, and ensuring that recruits will become adults without leaving the host. The author also indicated that "hyperparasitism" (a misuse of the term, which in fact refers to a parasite of a parasite, and not to a large number of parasites) is frequent and more than 1,200 juveniles of the related Parathemisto gaudichaudii were found in a single colony of 13 salps. Unfortunately, quantitative reports on hyperiids associated with medusae are sparse and the only data set available demonstrates rather low numbers of hyperiids per host specimen; Gasca (2005) described a new species on the basis of only one female found in a single host specimen, which was captured by a remote 


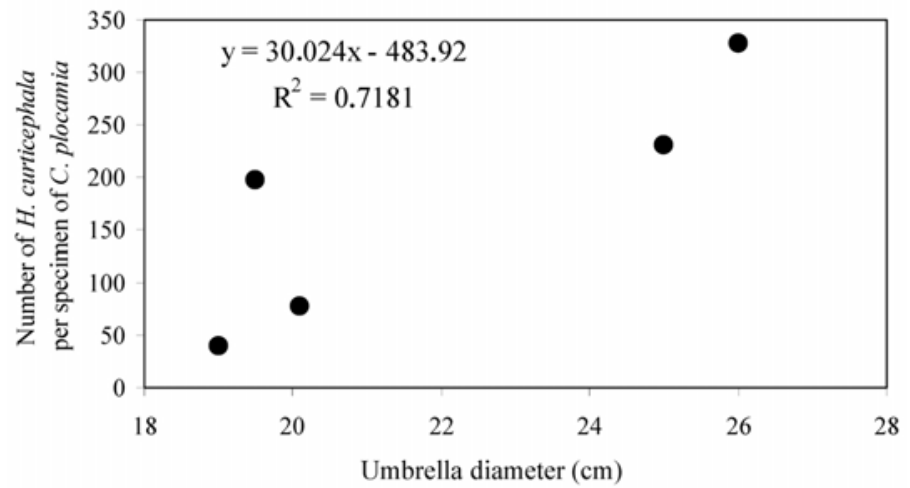

Figure 2

Relationship between umbrella diameter of $C$. plocamia and number of $\boldsymbol{H}$. curticephala associated with each medusa from Mejillones Bay, northern Chile

Relación entre el diámetro de la umbrela de C. plocamia y número de H. curticephala asociado a cada medusa procedente de Bahía de Mejillones, norte de Chile

operated vehicle in the Gulf of California. Buecher et al. (2001) analyzed samples of two Cnidarians, namely the Scyphozoan Chrysaora hysoscella and the Hydrozoan Aequorea aequorea off Namibia. From a total of 2,488 A. aequorea three hosted some specimens of hyperiids; the authors, however, pointed out that it was not sure that they lived in association because the amphipods were not embedded in the mesoglea of the jellyfish. In contrast, $37.3 \%$ of $870 \mathrm{C}$. hysoscella were parasitized by 1 to 10 $H$. medusarum; a maximum number of 43 individuals were recorded in a medusa of $52 \mathrm{~cm}$ diameter and $6.0 \mathrm{~kg}$ wet mass. Thus, in comparison with the Namibian $C$. hysoscella parasite burden, that of the Chilean $C$. plocamia is much higher. The most perspicuous explanation for such a strong difference refers to the sampling method. Conventional net sampling - as is the case for the Namibian study - is not adequate to study zooplanktonic associations, as individuals are commonly separated due to turbulences generated during the tows (Lima \& Valentin 2001). As a consequence medusae are damaged and hyperiids are likely to be lost (Lima \& Valentin 2001). The best way to record and study such associations is the collection of organisms in individual containers by SCUBA divers (Laval 1980). The present sampling method prevented the loss of hyperiids. The lacking report of planktonic hyperiids off northern Chilean may be an artefact consequence of the sampling devices used in local plankton research, which focus on copepods and euphausids (e.g. Hidalgo \& Escribano 2001, Escribano et al. 2007). To overcome this methodological bias, Laval (1980) suggested sampling using a 6 foot Isaacs-Kidd midwater trawl towed at 3 knots to catch a representative number of free living male hyperiids Vibilia armata.

A characteristic of hyperiids is the strong deviation from an adult 1:1 sex ratio (= reproductive population) (Laval 1980). Moreover, there are many reports and descriptions of both, parasitic and free-living new species with "unknown male" (vide in Laval 1980 for some examples). The present proportion of male:female (approximately 1:5) suggests that males are predominantly free-living and may only be sampled when an adequate sampling method is used.

The number of eggs observed in the brood pouch (127) agrees well with the values given (Laval 1980) for other Hyperiids associations.

With regard to feeding, Laval (1968) claims that during a 15-day period a specimen of the hyperiid Phronima curvipes living inside a barrel was able to ingest as much as 23 small blastozooids and 6 oozoids of the salp Salpa fusiformis, one tetrazoid colony of a Pyrosomid, two Pleurobranchia rhodopis and one specimen of a Leptomedusa of the genus Phialidium. The latter data strongly suggest that the studied hyperiid is an active depredator, revealing equilibrium between feeding rate of the hyperiids and the regeneration rate of the medusa tissue. From the insights into the feeding behaviour of hyperiids, Laval (1968) concludes that these amphipods can be considered as a parasitoid system. The term 'parasitoid' was erected for insects developing inside, or on another insect, using the host as a food source for larval stages and normally killing the host (Bush et al. 2001). The present gut contents of all dissected 
specimens $(\mathrm{N}=10)$ included small portion of mesoglea, suggesting that $H$. curticephala uses $C$. plocamia not only as substrate, but also as food source. This observation and the evidence given by Laval (1968) allow this hyperiid to be considered as a micropredator instead of a parasite or a parasitoid.

This record of $H$. curticephala, described from coastal waters of Paita Bay, northern Peru ( $5^{\circ} 04^{\prime}$ S) (Fig. 1), extends the known geographic distribution of this amphipod to $18^{\circ}$ of latitude southwards. Many aspects of the ecology and biology of the symbiosis remain to be studied.

\section{Acknowledgments}

This study was partly financed and conducted in the frame of the EU-INCO project CENSOR (Climate variability and El Niño Southern Oscillation: Implications for Natural Resources and Management, contract 511071) and is CENSOR publication 0358. Further support came from PBCT-CONICYT (Chile) grant CENSOR-RUE02 and a cooperative program between the Alfred Wegener Institute for Polar and Marine Research and the Instituto de Investigaciones Oceanológicas, Universidad de Antofagasta, Chile.

\section{Literature cited}

Buecher E, C Sparks, A Brierly, H Boyer \& M Gibbons. 2001. Biometry and size distribution of Chrysaora hysoscella (Cnidaria, Sciphozoa) and Aequorea aequorea (Cnidaria, Hydrozoa) off Namibia with some notes on their parasite Hyperia medusarum. Journal of Plankton Research 23: $1073-1080$.

Bush AO, JC Fernández, JW Esch \& JR Seed. 2001. Parasitism; The diversity and ecology of animal parasites, 566 pp. Cambridge University Press, Cambridge.

Dittrich B. 1992. Functional morphology of the mouthparts and feeding strategies of the parasitic amphipod Hyperia galba (Montagu, 1813). Sarsia 77: 11-18.

Escribano R, P Hidalgo, H González, R Giesecke, R Riquelme-Bugueño \& K Manríquez. 2007. Seasonal and interannual variation of mesozooplankton in the coastal upwelling zone off central-southern Chile. Progress in Oceanography 75: 470-485.

Gasca R. 2003. Hyperiid amphipods (Crustacea: Peracarida) in relation to a cold-core ring in the Gulf of Mexico. Hydrobiologia 510: 115-124.

Gasca R. 2005. Hyperoche shihi sp. nov. (Crustacea: Peracarida: Amphipoda): a symbiont of a deep-living medusa in the Gulf of California. Journal of Plankton Research 27: 617-621.

Gasca R \& SHD Haddock. 2004. Association between gelatinous zooplankton and hyperiid amphipods (Crustacea: Peracarida) in the Gulf of California. Hydrobiologia 530/ 531: 529-535.

Hidalgo P \& R Escribano. 2001. Succession of pelagic copepod species in coastal waters off northern Chile: the influence of the 1997-1998 El Niño. Hydrobiologia 453: $153-160$

Laval P. 1968. Observations sur la biologie de Phronima curvies Voss. (Amphipode Hypéride) et description du male adulte. Cahiers de Biologie Marine 9: 347-362.

Laval P. 1980. Hyperiid amphipods as crustacean parasitoids associated with gelatinous zooplankton. Oceanography and Marine Biology: an Annual Review 18: 11-56.

Lima MCG \& JL Valentin. 2001. New records of amphipods Hyperiidae in association with gelatinous zooplankton. Hydrobiologia 448: 229-235.

Palma S. 1994. Composición y distribución del macroplancton gelatinosos recolectado frente a la costa central de Chile. Revista de Biología Marina 29: 23-45.

Palma S \& S Rosales. 1995. Composición, abundancia y distribución estacional del macroplancton de la bahía de Valparaíso. Investigaciones Marinas 23: 49-66.

Shulenberger E. 1978. Vertical distributions, diurnal migrations and sampling problems of hyperiid amphipods in the North Pacific central gyre. Deep-Sea Research 25: 605-623

Thiel M, EC Macaya, E Acuña, WE Arntz, H Bastías, K Brokordt, P Camus, JC Castilla, LR Castro, M Cortés, CP Dumont, R Escribano, M Fernández, JA Gajardo, CF Gaymer, I Gomez, AE González, HE González, PA Haye, JE Illanes, JL Iriarte, DL Lancellotti, G LunaJorquera, C Luxoro, PH Manriquez, V Marín, P Muñoz, SA Navarrete, E Pérez, E Poulin, J Sellanes, HH Sepúlveda, W Stotz, F Tala, A Thomas, CA Vargas, JA Vásquez \& JMA Vega. 2007. The Humboldt Current system of northern and central Chile oceanographic processes, ecological interactions and socioeconomic feedback. Oceanography and Marine Biology: an Annual Review 45: 195-344.

Vader W. 1983. Associations between amphipods (Crustacea: Amphipoda) and sea anemones (Anthozoa: Actinaria). Memoirs Australian Museum 18: 141-153.

Vinogradov ME \& TN Semenova. 1985. A new species of the genus Hyperia (Crustacea, Amphipoda) from the coastal waters of Peru. Zoologichesky Zhurnal 64: 139-143. [in Russian] 